
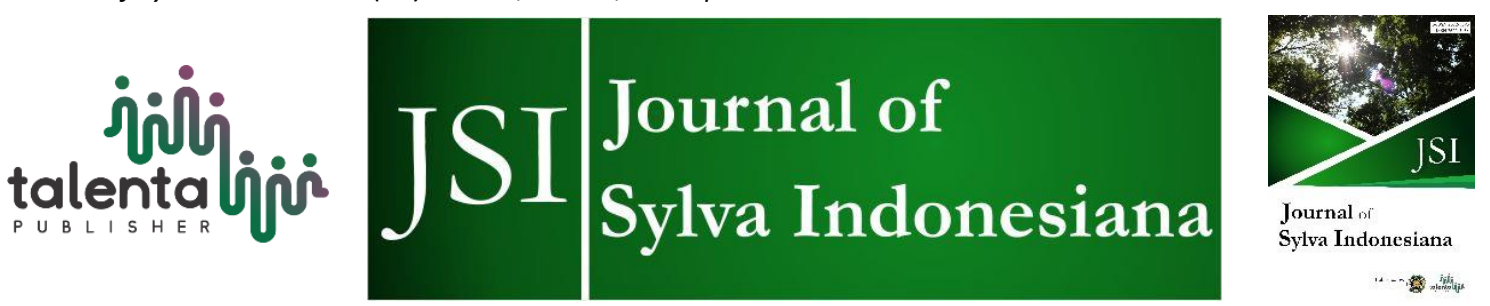

\title{
Growth Rate of Rhizophora apiculata Propaguls in Two Sylvofishery Ponds in Tanjung Rejo Village Percut Sei Tuan District
}

\author{
Delvian $^{1}$, Indri Marita Siahaan ${ }^{2}$, Ridahati Rambey $^{3}$ \\ ${ }^{1,2,3}$ Faculty of Forestry, Universitas Sumatera Utara, Medan, Indonesia
}

\begin{abstract}
Research on growth rate of Rhizophora apiculata propaguls was carried out in Tanjung Rejo Village, Deli Serdang Regency, North Sumatra. The purpose of this study was to compare growth of Rhizophora apiculata in two silvofishery ponds. The measured parameters were height, diameter and number of leaves. During 12 weeks of observation, the highest Rhizophora apiculata seedling growth of was ponds A, those were $1.8 \mathrm{~cm}$ in height and $0.2 \mathrm{~cm}$ in diameter (5 week), the highest number of leaves was 7 . At the ponds $\mathrm{B}$, the highest seedling growth was observed on fifth week those were $1.8 \mathrm{~cm}$, with the diameters increasing was 0.05 to $0.1 \mathrm{~cm}$ and number of leaves range from 0 to 5 . It can be conclude that Rhizophora apiculata growth is better at ponds A than ponds B.
\end{abstract}

Keyword: Growth Rate, Rhizophora apiculata, Sylvofishery

Received 13 September 2018 | Revised 19 February 2019| Accepted 02 April 2019

\section{Introduction}

Mangroves species can be growth well in saline environment. Rhizophora apiculata, is belonging member of mangrove species from Rhizophoraceae family, that commonly growth in the muddy soil with good granule, deep and waterlogged on normal tides. Rhizophora apiculata does not adapt well on hard substrates with high sand composition. The domination level of this species can reach $90 \%$ of all vegetation in a location. This species grows well in tidal water which have a strong influenced by the input of fresh water permanently [1]. Mangrove ecosystem is currently experiencing damage due to excessive land conversion. Population growth especially in coastal areas, land conversion into residential areas, aquaculture, port infrastructure and industry has resulted in changes in land use and excessive use of natural resources. Mangrove ecosystems are rapidly decreased and damaged [2].

\footnotetext{
*Corresponding author at: Universitas Sumatera Utara , Padang Bulan, Medan, 20155, Indonesia E-mail address: delvianibrahim@yahoo.co.id
} 
Although mangrove ecosystems are classified as recoverable resources, if the large scale conversion continuously without restoration effort, then the ability for restoring the ecosystem was low, these recoverable will be slow. In damaged ecosystems, silvofishery systems can be conducted by planting mangroves in these ponds [3].

The concept of silvofishery combined with fishponds and mangrove planting was expected to bridge these two interests, so that aquaculture pond activities do not sacrifice the sustainability of mangrove ecosystems. The advantages of applying silvofishery systems are employment increase, overcoming food and energy problems and maintaining the stability of micro ecosystems and soil conservation [4]. Rhizophora apiculata was a good decision considering it cultivates easily and the seedlings are abundant compared to other species. The study aimed to compare the growth of Rhizophora apiculata on two silvofisheries.

\section{Materials and Methods}

2.1. Materials: This research was conducted in Tanjung Rejo Village, Percut Sei Tuan Subdistrict, Deli Serdang Regency, North Sumatra. Thirthy 1.5 year Rhizophora apiculata seedlings of were used for this study. The site salinity was 20 to $30 \mathrm{ppt}$.

2.2. Methods: We were using the examination of different ecosystem characteristics as the method, and the parameters were mud depth, distance from the coastline, level of water salinity and nutrients. The height, diameter and number of leaves was observed for seedling growth. The growth of Rhizophora apiculata seedlings in two ponds data was analysed descriptively. To determine the growth differences, an analysis was performed using the t-Test According to [5].

\section{Results And Discussion}

\subsection{The Ecosystem Characteristic on the Ponds}

The result on soil characteristic of ponds A and B with different ecosystem characteristics, presented on Table 1 .

Table 1. The Characteristics of Sylvofishery Ponds at Tanjung Rejo Village, Percut Sei Tuan Sub-District. Source : [6]

\begin{tabular}{|c|c|c|c|c|c|c|c|c|}
\hline \multirow[b]{3}{*}{ Pond } & \multirow{3}{*}{$\begin{array}{l}\text { Pond } \\
\text { Area } \\
\text { (Ha) }\end{array}$} & \multirow{3}{*}{$\begin{array}{l}\text { Distance } \\
\text { from } \\
\text { Coastline } \\
\text { (m) }\end{array}$} & \multicolumn{6}{|c|}{ Ecosystem Characteristic } \\
\hline & & & \multirow[b]{2}{*}{$\begin{array}{l}\text { Mud } \\
\text { Depth } \\
\text { (cm) }\end{array}$} & \multirow[b]{2}{*}{$\mathrm{pH}$} & \multirow[b]{2}{*}{$\begin{array}{c}\text { Water } \\
\text { Salinity }\end{array}$} & \multicolumn{3}{|c|}{ Nutrients } \\
\hline & & & & & & $\begin{array}{c}\mathrm{C}- \\
\text { organic } \\
(\%)\end{array}$ & $\begin{array}{c}\text { N-total } \\
(\%)\end{array}$ & $\mathrm{P}(\mathrm{ppm})$ \\
\hline A & 6 & 120 & 35.4 & 5.81 & 24 & 4.68 & 1.25 & 9.51 \\
\hline B & 0.5 & 50 & 16.8 & 5.60 & 28 & 5.42 & 1.08 & 10.28 \\
\hline
\end{tabular}

1. Distance from the Coastline

The distance from the coastline is one of factors influencing mangrove growth. The result showed that growth of mangrove on $120 \mathrm{~m}$ from the coastline is better than those on $50 \mathrm{~m}$. It 
migh be as a result of tidal waves effect. Although pond A distance was far than B, the water circulation was better. The gates were opened and closed regularly every day. This is in accordance with the statement of [7] which states that tides are one of the factors that influence mangrove occurence.

\section{Mud Depth}

The mud depth on pond A and pond B were $35.4 \mathrm{~cm}$ and $16.8 \mathrm{~cm}$, respectively. Pond A had better mud content and promoted better growth for Rhizophora apiculata. This is in accordance with the statement of [1] that Rhizophora apiculata commonly not well adapted in hard substrate with high sand composition. The mud content on pond B was lower due to shorter tides, causing less mud sedimentation. In contrary, pond A had longer tides and constant water logging, resulting more mud sedimentation. According to [8] tides that occur for a long time with minimum flow causing thick accumulation of mud. Tides that occur in a short time with a minimum flow causing thin accumulation of mud.

\section{Water Salinity}

Water salinity on pond A and B were $24 \mathrm{ppt}$ and $28 \mathrm{ppt}$, respectively. According to [9] most mangroves growth on estuaries with salinity level 10-30 ppt. High salinity level which exceeding common sea salinity ( $\pm 35 \mathrm{ppt}$ ) can adversely affect mangrove vegetation, due to the impact of negative osmosis pressure. Both ponds (A and B) classified as salty water category which salinity was in range of $0.5 \mathrm{ppt}$ to $30 \mathrm{ppt}$.

\section{Nutrients}

Community activities caused the remaining materials to be swept into pond $\mathrm{B}$ area so that the $\mathrm{C}$ organic content became high. In addition, undecomposed mangroves litter causing organic and inorganic materials content in the waters to increase. According to [10] organic carbon produces from a variety of natural materials, especially sediments, which are full of residual inputs from human activities that add organic material transported by the river.

Nitrogen is one of nutrients that influences mangrove growth. According to [11], nitrogen in pond indicates positive effect on increasing nutrients concentration derived from fallen leaves, thus influencing mangrove growth. The total nitrogen content in pond A and B classified into very low, which were $1.25 \%$ and $1.08 \%$, respectively. The low $\mathrm{N}$ nutrient content in both ponds was caused by large amount of inorganic waste that can inhibit the process of nitrogen nutrients form in the soil. The amount of inorganic wastes will affect the number of bacteria that play in the nitrification process [12].

The total $\mathrm{P}$ content in in pond $\mathrm{A}$ and $\mathrm{B}$ were categorized as moderate, which were $9.25 \mathrm{ppm}$ and 10.28 ppm, respectively. P-organic is a type of $\mathrm{P}$ element found in the soil. To utilize these element, plants need to transform to P-anorganic. 


\subsection{The Growth of Rhizophora apiculata seedling}

The results of t-test on two sylvofishery ponds were presented in Table 2. There did not significant difference between Rhizophora apiculata seedling on pond A and B. The difference were significant on diameter and number of leaves on both ponds.

Table 1 T-test for the growth of Rhizophora apiculata in ponds A and B in Percut Sei Tuan Village

\begin{tabular}{lcccc}
\hline \multicolumn{1}{c}{ Parameter } & S (A-B) & t-count & t-table & Significancy \\
\hline Height & 4.96 & 0.65 & 2.131 & $\mathrm{~ns}$ \\
Diameter & 0.1 & 374 & 2.131 & $\mathrm{~s}$ \\
Number of leaves & 15.73 & 2.48 & 2.131 & $\mathrm{~s}$ \\
\hline
\end{tabular}

Description: s: significant, $\quad$ ns: not significant, $S(A-B)=$ standard deviation

\subsection{The Seedling Height of Rhizophora apiculata}

The high growth of mangrove Rhizophora apiculata was affected by primary meristem tissue activities, causing the stem to grew longer. The growth of Rhizophora apiculata seedlings was shown in Figure 1.

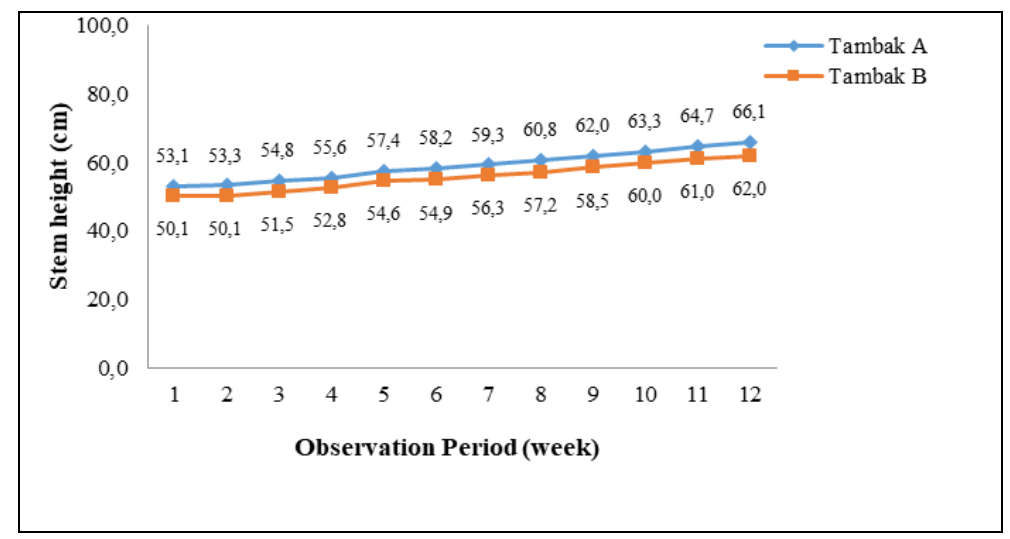

Figure 1 The average height of of Rhizophora apiculata in ponds A and B in Percut Sei Tuan Village

Based on Figure 1, the average seedling height of Rhizophora apiculata in ponds A and B for 12 weeks observation, increasing every week. The highest increase $(1.8 \mathrm{~cm})$ in pond A occurred on the fifth week of observation, and the lowest occured in the second week was $0.2 \mathrm{~cm}$. The highest increase in pond B occurred on the fifth week of observation, which was $1.8 \mathrm{~cm}$, but there were no increase on the second week. According to [13], there are three environmental factors and one genetic factor that provides very significant influence on height growth, namely the content of soil mineral nutrients, soil moisture, sunlight, and the balance of genetic traits between growth in height and diameter.

Based on the results of the t-test (Table 2), the growth of Rhizophora apiculata seedlings was not significantly in ponds $\mathrm{A}$ and $\mathrm{B}$, due to similar spacing $(1 \mathrm{~m}$ by $1 \mathrm{~m})$, size and age of Rhizophora apiculata seedlings. Therefore, the growth rate difference between pond A and B was not significant. According to [14] the spacing is an important factor to provide optimal 
space for the growth mangrove seedlings and will influence the light use so that it also affects the uptake of nutrients, water and air.

\subsection{Diameter of Rhizophora apiculata Seedling}

The average stem diameter of Rhizophora apiculata seedlings can be seen in Figure 2. After twelve weeks of observation the largest diameter increase occured on pond A, which was 0.2 $\mathrm{cm}$ in third week. The diameter increase on pond $\mathrm{B}$ was $0.1 \mathrm{~cm}$, it might influenced by the organic matter or nutrients content in the substrate. The $\mathrm{C}$ organic content of pond $\mathrm{A}$ and $\mathrm{B}$ according to laboratory analysis result were $4.68 \%$ and $5.42 \%$, respectively. C organic content on mangrove-dominated vegetation is strongly influenced by tidal waves. The soil is often reduced at high tide and oxidized at low tide. This is in accordance with the statement of [15], changes in seedling diameter influenced by the content of organic matter or nutrients in the substrate.

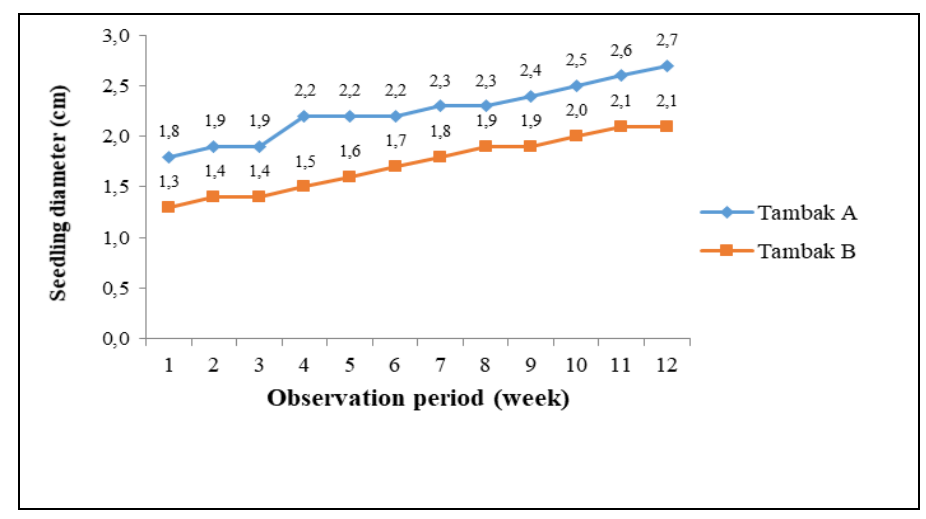

Figure 2 The average diameter of the seedlings of Rhizophora apiculata in ponds A and B in Percut Sei Tuan Village

The diameter growth in ponds A and B were significantly different. The sandy mud soil substrate at the site was sugested to causes the diameter increase. Pond A contained more mud than pond B which has a slightly harder soil substrate. Nutrients in mud affected diameter growth. This condition also in accordance with [16] who stated that mud is one of the growth factors that determine the height and diameter of plants. The growth affected by the availability of nutrients contained in the mud content.

The diameter growth was slower than height increase, and it was not obviously visible during the observation. We suspected the observation period was relatively short. The significant difference also caused by the different growth environment. Since pond A was daily flooded by nutrient-carrier waves, the growth of Rhizophora apiculata seedling was higher than pond B, which were flooded only when on tide. According to [7] tides is one of the factors that affect the growth of mangroves, especially the mangrove root system.

Muddy substrate is a good place to support seedling growth. This is in accordance with [17] that mangrove forests can grow on the basic substrate of sand, mud, coral and rocks, but the best growth is found in the mud base substrate. In other basic substrates, growth is generally poor and tends to be slow. 


\subsection{Number of Leaves of Rhizophora apiculata Seedlings}

Changes in condition between dry season to rainy season on August - November caused pest attacks to increase, that caused variability of seedling growth. Many seedlings were stunted or slow growth. There was also increase and decrease the number of leaves for each observation on both ponds. According to [18] the increase of leaves number indicates that growth of Rhizophora apiculata seedlings and the fallen leaves is an effort to adapt to the environment. The average number of leaves of Rhizophora apiculata on pond A and B after twelve weeks of observation is presented on Figure 3.

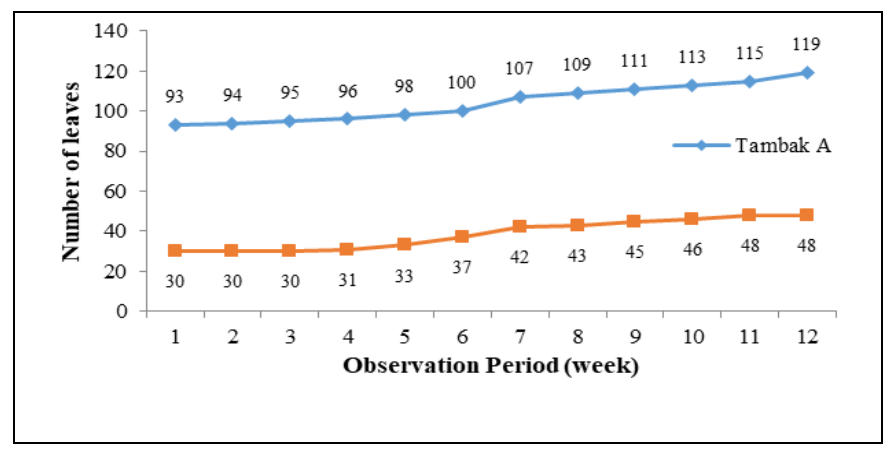

Figure 3 The average number of leaves of Rhizophora apiculata seedlings in pond A and B on Percut Sei Tuan Village

Based on figure 3, the average number of leaves of Rhizophora apiculata after twelve weeks of observation on pond A and B were 0 to 7 leaves and 0 to 5 leaves, respectively. Pond A was suffering from caterpillar attack and pond B was infested by small crabs, which marked by small bites on seedlings. Caterpillars fed the bottom surface of the leaves (Figure 4), prompted the leaves turned yellow and fell out, causing the seedling difficult to adapt to the environment. According to [19], the caterpillars are always in the pocket. These caterpillars are very dangerous for being the cause of mangroves to shed their leaves and unable to carry out photosynthesis to form leaf tissue. Caterpillars feed on leaves so that the leaves will be hollow, dry and fall.

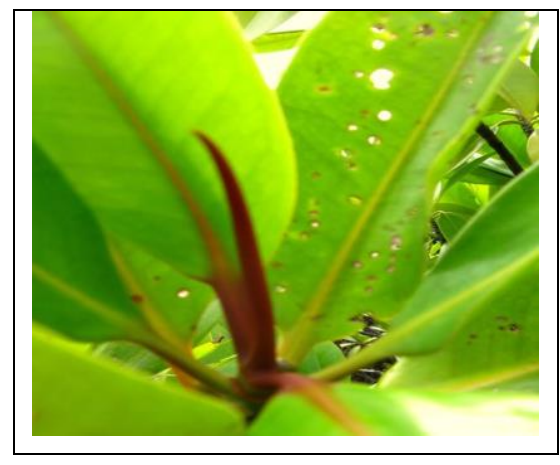

Figure 4 Pest attack on the leaves of Rhizophora apiculata

The increase in the number of Rhizophora apiculata leaves in ponds A and B was significantly different, influenced by diameter of seedling condition itself. According to [20], the wide of diameter is directly affect the size of the xylem. Larger xylem will transport more nutrients and water from the soil, then causing the increase of photosynthesis quality and number of leaves. 
The number of leaves is important for photosynthesis process, and when it fall out will become decomposition material which useful for biotas and organisms. This is in accordance with [21] statement that photosynthesis is a process that becomes the key to the ongoing process of metabolism in plants.

\section{Conclusion}

The growth of Rhizophora apiculata seedlings in pond A was better than in pond B. There was a significant difference between two sylvofishery ponds in the parameters of stem diameter and number of leaves, but not in the height.

\section{REFERENCES}

[1] D.N. Amin, H. Irawan, and A. Zulfikar, Relationship between Substrate Type and Density of Vegetation Rhizophora sp in Mangrove Forest of Sungai Nyirih, Tanjung Pinang District, Tanjung pinang City, Faculty of Marine and Fisheries Sciences, Raja Ali Haji Maritime University, 2015.

[2] Z. Syam, Yunasfi, M. Dalimunthe, Effect of Mangrove Forest on Production of Wind Shrimp (Penaeus monodon) in Sylvofishery Pond in Tanjung Ibus Village, Secanggang District, Langkat Regency, Faculty of Agriculture, University of North Sumatra, 2013.

[3] M. Gufran, and H.K. Kordi, Mangrove Ecosystem: Potential, Function and Management, Rineka Cipta, Jakarta, 2012.

[4] K. Wibowo, and T. Handayani, "Preservation of Mangrove Forest through Sylvofishery Approach," Journal of Environmental Technology, vol. 7, no. 3, 2006.

[5] Kusriningrum, Trial Design, Airlangga University Press, Surabaya, 2010.

[6] S. Hardjowigeno, Soil Science, Akademika Pressindo, Jakarta, 2007.

[7] A.D. Setyawan, K. Winarno, and P.C. Purnama, "Mangrove Ecosystems in Java: Current Conditions," Biodiversity, vol. 4, no. 2, pp. 133-145. 2005.

[8] A. Darmawan, "The Role of Mangrove Rehabilitation in Accumulating Mud Substrates at Brebes Beach. Faculty of Forestry, Gadjah Mada University," Journal of Forestry Science, no. 2, pp. 29-42. 2002.

[9] E. Jumiati, "Growth of Rhizophora mucronata and Rhizophora apiculata in Berlatung Region," Journal of Tropical Forest Management, vol. 14, no. 3, pp. 104-110. 2008.

[10] T. Pratono, M. Razak, and I. Gunawan. "Organochlorine Pesticides in Sediment Coastal Estuary Citarum, Jakarta Bay. The Important Role of the Sediment Fine Fraction as the DDT Pentransport and its Diagnosis Process." E-Journal of Technology and Ocean Tropical, vol. 1, no. 2, pp. 11-21. 2009.

[11] A. Fauzi., A.K. Skidmore, G.H. Van., Schlerf, and I.M.A. Heitkonig, Shrimp Pond Effluent Dominates Foliar Nitrogen in Disturbed Mangrove as Mapped Using Hyperspectral Imagery. Marine Pollution Bulletin $76: 42-51.2013$.

[12] N. Pradipta, Study of Nitrogen $(N)$ and Phosphorus (P) Content in Mangrove Sediments in Surabaya Wonorejo and Coastal Areas in Tuban Regency, Airlangga University Press, Surabaya, 2016.

[13] L.S. Davis, and K.N. Jhonson, In: Mc Graw (Ed.), Forest Management, 3rd ed.. Hill Book Company, New York, 1987.

[14] A.Y.R Doni, S. Nasution, and Feliatra. The Effect of Planting Spacing on Growth and Life Graduation of Mangrove Seeds (Avicennia marina) in Anak Setatah Village, Rangsang Barat Subdistrict, Meranti Islands Regency, Riau Province, Faculty of Marine and Fisheries, University of Riau, 2016.

[15] Herpinawati, D. Zulkifli, and Sarno, "Growth Rate and Biomass of Rhizophora apiculata in Delta Upang Waters of Banyuasin, South Sumatra. Faculty of 
Mathematics and Natural Sciences Sriwijaya University,” Maspari Journal, no. 01, pp. 59-62. 2010.

[16] C.M. Duarte, O.G. Hansen, and U. Thampanya, "Relationship between Sediment Conditions and Mangroves Rhizophora apiculata Seedling Growth and Nutrient Status," Marine Ecology Progress Series, no. 175, pp. 227-283. 1998.

[17] H. Kurniawan, Propagul Rhizophora mucronata Growth Rate in Various Shade Intensities in Concong Village in Indragiri Hilir Regency, Riau Province, Faculty of Fisheries and Marine Sciences, University of Riau, 2013.

[18] K. Fahmi, Z. Dahlan, and Sarno, Life Success Rate of Mangrove Seeds Rhizophora mucronata, Rhizophora apiculata and Bruguiera gymnorrhiza in Delta Upang Banyuasin, South Sumatra, Sriwijaya University, 2010.

[19] A. Meilin and M. Sugihartono, "Preference Test for Sacrificial Caterpillars (Pteroma sp) against Several Mangrove Plants," Universitas Batang Hari Jambi Scientific Journal Special Edition, pp. 57-60. 2009.

[20] N.S.S. Gonzales, "Structure and Function of Wood in Mangroves," Thesis, The University of Queensland, Australia, 2012.

[21] Irwanto, "Effect of Shade Differences on Seed Growth of Shorea sp in Nursery," Thesis, Gadjah Mada University, Yogyakarta, 2006. 